\title{
INTEGRASI SPASIAL SISTEM DINAMIK UNTUK ANALISIS PERUBAHAN POLA ALIRAN SUNGAI DAN DAERAH GENANGAN DI PANTAI SURABAYA-SIDOARJO
}

\author{
Bangun Muljo Sukojo ${ }^{1)}$, Regina Verra Santiara Y.P ${ }^{1)}$, Erma Suryani ${ }^{1)}$ \\ ${ }^{1}$ PPIDS LPPM Institut Teknologi Sepuluh Nopember \\ e-mail: bangunms@gmail.com
}

\begin{abstract}
Abstrak. Faktor penyebab terjadinya genangan dan banjir adalah intensitas curah hujan lebih besar daripada perhitungan dalam perencanaan drainase dan intensitas hujan sesuai dengan perencanaan akan tetapi limpasan air hujan tidak mampu ditampung oleh sistem drainase yang ada. Analisa spasial dapat digunakan untuk mendapatkan pola aliran sungai dan daerah rawan genangan. Analisa spasial dilakukan dengan menggunakan beberapa tipe data spasial yaitu: citra satelit penginderaan jauh untuk memetakan tutupan lahan dan peta-peta tematik untuk melihat konfigurasi bentang lahan. Tujuan utama dari penelitian ini adalah mengetahui dan menganalisa perubahan pola aliran sungai dan daerah genangan di Pesisir Surabaya-Sidoarjo. Hasil penelitian ini menunjukkan bahwa Daerah pesisir Surabaya bagian Utara sampai perbatasan Sidoarjo di dominasi oleh pola aliran Paralel, sedangkan daerah pesisir Sidoarjo lebih di dominasi oleh pola aliran sungai Dendritik. Pola aliran sungai dari tahun 2009 hingga 2013 relatif tetap. Berdasarkan tingkat kerawanannya, kawasan pesisir pantai Surabaya-Sidoarjo didominasi kelas genangan sangat rawan. Hal ini terjadi karena persebaran hujan dengan intensitas yang tinggi di daerah tersebut. Sehingga mengindikasikan bahwa selain tutupan lahan, curah hujan juga cukup mempengaruhi tingkat kerawanan daerah genangan. Pada tahun 2009 dan 2013, diperkirakan bahwa Sub DAS Jomblong dan Sub DAS Greges merupakan daerah rawan genangan karena memiliki nilai debit maksimum yang melebihi debit eksistingnya.
\end{abstract}

Kata Kunci: daerah rawan genangan; pola aliran sungai; analisa spasial; citra satelit penginderaan jauh

\section{PENDAHULUAN}

Genangan termasuk dalam suatu kondisi alam yang disebabkan dari beberapa faktor, salah satunya genangan yang diakibatkan karena limpasan air hujan. Selain itu, tutupan lahan juga mempengaruhi aspek hidrologi kawasan tersebut. Perubahan tutupan lahan pada suatu daerah tangkapan air akan mempengaruhi aspek hidrologi.

Perubahan karakteristik hidrologi akibat perubahan tutupan lahan antara lain adalah erosi, debit banjir dan infiltrasi (Edi, 2012). Munadhir dalam Susilowati (2006) menjelaskan bahwa penyebab terjadinya genangan dan banjir adalah intensitas curah hujan lebih besar daripada perhitungan dalam perencanaan drainase dan intensitas hujan sesuai dengan perencanaan akan tetapi limpasan air hujan tidak mampu ditampung oleh sistem drainase yang ada.

Untuk penyebab yang lainnya dapat disebabkan karena kerusakan sistem drainase akibat peristiwa ulah manusia yang secara tidak langsung menyebabkan berkurangnya infiltrasi.
Sehingga dapat dikatakan akan memperbanyak daerah yang tergenang jika terjadi peresapan air yang tidak maksimal.

Berdasarkan letak geografisnya, kawasan pesisir Surabaya-Sidoarjo merupakan salah satu daerah dataran rendah rawan genangan dengan ketinggian yang hampir sejajar dengan permukaan air laut rata-rata atau Mean Sea Level (MSL). Untuk itu perlu dilakukan analisis perubahan pola aliran sungai dan daerah rawan genangan di Pantai Surabaya-Sidoarjo.

Analisa spasial dapat digunakan untuk mendapatkan pola aliran sungai dan daerah rawan genangan. Analisa spasial dilakukan dengan menggunakan beberapa tipe data spasial yaitu: citra satelit penginderaan jauh untuk memetakan tutupan lahan dan peta-peta tematik untuk melihat konfigurasi bentang lahan. Tujuan utama dari penelitian ini adalah mengetahui dan menganalisa perubahan pola aliran sungai dan daerah genangan di Pantai Surabaya-Sidoarjo. 


\section{Penelitian Terdahulu}

Berdasarkan Mirzanur Idris (2007) analisis limpasan dan penentuan daerah genangan di Kabupaten Lamongan menggunakan Citra SPOT 2, dari penelitian tersebut didapatkan bahwa wilayah limpasan dan genangan air hujan memiliki ketinggian yang relatif sangat rendah yaitu 0-12.5 meter berdasarkan peta visualisasi limpasan dan genangan air hujan. Wilayah dampak limpasan dan genangan air hujan tersebut berupa sawah, kebun dan ladang, badan air dan pemukiman.

Berdasarkan Bioresita Filsa (2013) analisa potensi genangan berdasarkan data curah hujan global berbasis penginderaan jauh, dari penelitian tersebut didapatkan bahwa analisa hubungan antara data curah hujan TRMM dengan genangan menghasilkan perubahan curah hujan yang tidak terlalu berpengaruh pada perubahan luas genangan. Curah hujan akan berpengaruh apabila disertai dengan variabel atau parameter-parameter yang lain seperti ketinggian wilayah, kelerengan, penggunaan lahan, dan jenis tanah untuk dapat membuat pemodelan prakiraan genangan yang tepat.

Dari beberapa penelitian mengenai daerah genangan yang telah dilakukan di atas, maka analisa perubahan pola hidrologi dan daerah genangan merupakan hal menarik untuk dikaji dengan mengaplikasikan teknologi penginderaan jauh.

\section{Penginderaan Jauh}

Penginderaan jauh adalah ilmu dan seni untuk memperoleh informasi tentang suatu objek, daerah, atau fenomena melalui analisis data yang diperoleh tanpa kontak langsung dengan objek, daerah, atau fenomena yang dikaji (Lillesand dan Kiefer, 1994).

Setiap citra satelit digital yang dihasilkan oleh sensor mempunyai sifat data yang khas, sifat tersebut dipengaruhi oleh sifat orbit satelit, kepekaan sensor terhadap panjang gelombang elektromagnetik, jalur transmisi yang digunakan, objek, dan sumber tenaga radiasinya. Sifat orbit satelit dan cara operasi sistem sensor dapat mempengaruhi resolusi dan ukuran piksel. Data penginderaan jauh dapat berupa data citra dan data non-citra. Data citra antara lain data yang bersifat optik, analog, dan digital. Sedangkan data non-citra berupa grafik, diagram, dan numerik. Citra hasil rekaman sensor harus dikoreksi, antara lain dengan menggunakan koreksi radiometrik, koreksi geometrik, dan koreksi atmosferik (Purwadhi, 2001).

Salah satu contoh citra satelit penginderaan jauh adalah Land Satellite (Landsat). Landsat merupakan program tertua dalam perangkat observasi bumi. Landsat dimulai tahun 1972 dengan nama Earth Resources Technology Satellite (ERTS-1). Satelit ini merupakan satelit sumber daya alam yang pertama. Satelit Landsat terdiri dari beberapa seri yaitu: Landsat-1, Landsat-2, diteruskan 3, 4, 5, 6, Landsat 7 dimana merupakan bentuk baru dari Landsat 6 yang gagal mengorbit dan yang terakhir adalah Landsat 8.

Citra satelit Landsat-7 merupakan citra Landsat dengan resolusi spasial $30 \mathrm{~m} \times 30 \mathrm{~m}$ pada band 1,2 , 3, 4, 5, 7 dan $60 \mathrm{~m} \times 60 \mathrm{~m}$ pada band 6 (thermal). Landsat-7 dilengkapi dengan Enhanced Thematic Mapper Plus (ETM+) yang merupakan kelanjutan dari program Thematic Mapper (TM) yang diusung sejak Landsat-5. Saluran pada satelit ini pada dasarnya adalah sama dengan 7 saluran pada TM, namun diperluas dengan saluran 8 yaitu Pankromatik. Saluran 8 ini merupakan saluran beresolusi tinggi yaitu seluas 15 meter.

\section{Pola Aliran Sungai dan Genangan}

Pola aliran merupakan pola dari organisasi atau hubungan keruangan dari lembah-lembah, baik yang dialiri sungai maupun lembah yang kering atau tidak dialiri sungai. Pola aliran yang digunakan bisa dibedakan dengan membedakan garis yang dijadikan tanda pola aliran tersebut. Menurut (tim geografi dalam Ardi, 2010) macam-macam pola aliran adalah pola aliran dendritik, trellis, annular, centripetal.

Menurut Isnugroho dalam Ardi (2010), kawasan rawan banjir (genangan) merupakan kawasan yang sering atau berpotensi tinggi mengalami bencana banjir sesuai karakteristik penyebab banjir. Daerah genangan dapat dipengaruhi oleh intensitas curah hujan, jenis tutupan lahan, kemiringan lereng, dan jenis tanah. 
Dalam penelitian ini definisi genangan dibatasi pada genangan yang disebabkan oleh limpasan air yang melebihi kapasitas penyaluran sistem pengaliran air yang terdiri dari sistem sungai alamiah dan sistem drainase buatan manusia. Dari pembatasan definisi tersebut, parameter yang digunakan untuk menentukan daerah rawan genangan dalam penelitian ini adalah sebagai berikut:

- Curah hujan (curah hujan adalah jumlah air hujan yang turun pada suatu daerah dalam waktu tertentu);

- Jenis tanah (Jenis tanah merupakan bagian yang mempengaruhi daya serap (infiltrasi) air limpasan);

- Tata guna lahan (tata guna lahan adalah sebuah pemanfaatan lahan dan penataan lahan yang dilakukan sesuai dengan kondisi alam).

Ketinggian dan kelerengan tidak dimasukkan sebagai parameter karena lokasi studi dianggap sebagai daerah yang relatif datar sehinga tidak memberikan pengaruh yang signifikan.

Metode yang digunakan yaitu skoring dan pembobotan dari parameter tersebut. Nilai skor dan pembobotan yang digunakan dapat dilihat pada Tabel 1.

Nilai skor dan pembobotan yang diberikan didasarkan dari studi literatur yang disesuaikan dengan kondisi di lapangan. Kriteria tingkat kerentanan dikategorikan dalam 4 kelas, yaitu kurang rentan, rentan, sangat rentan dan genangan permanen.

Menurut Isnugroho (2006), salah satu jenis genangan dilihat dari aspek penyebabnya adalah genangan yang disebabkan oleh hujan yang lama, dengan intensitas rendah (hujan siklonik atau frontal) selama beberapa hari. Dengan kapasitas penyimpanan air yang dimiliki oleh masing-masing Satuan Wilayah Sungai (SWS) yang akhirnya terlampaui, maka air hujan yang terjadi akan menjadi limpasan yang selanjutnya akan mengalir secara cepat ke sungai-sungai terdekat, dan meluap menggenangi areal dataran rendah di kiri-kanan sungai.

Oleh karena itu, selain parameter tutupan lahan, curah hujan dan jenis tanah, parameter lain yang dapat digunakan untuk menentukan daerah rawan genangan adalah memperhatikan Daerah Aliran Sungai (DAS) dan menghitung debit maksimumnya.

Tabel 1. Skor dan Pembobotan Parameter Genangan.

\begin{tabular}{|c|c|c|c|c|}
\hline Variabel & Sub Variabel & Skor & Bobot & Total \\
\hline \multirow[t]{3}{*}{ Curah Hujan } & $<1452 \mathrm{~mm} /$ tahun & 3 & 3 & 9 \\
\hline & 1452 - $1470 \mathrm{~mm} /$ tahun & 5 & & 15 \\
\hline & $1470-2789 \mathrm{~mm} /$ tahun & 7 & & 21 \\
\hline \multirow[t]{4}{*}{ Jenis Tanah } & Aluvial Hidromorf & 7 & 1 & 7 \\
\hline & Aluvial Kelabu & 5 & & 5 \\
\hline & Aluvial Kelabu Tua & 5 & & 5 \\
\hline & Grumosol Kelabu Tua & 9 & & 9 \\
\hline \multirow[t]{5}{*}{ Tutupan Lahan } & Tambak & 9 & 1 & 9 \\
\hline & Rawa/Hutan Mangrove & 7 & & 7 \\
\hline & Rumput/Tanah Kosong & 5 & & 5 \\
\hline & Pemukiman & 6 & & 6 \\
\hline & Empang & 8 & & 8 \\
\hline
\end{tabular}

Sumber : (Primayuda (2006) dalam Suhardiman) 


\section{METODOLOGI}

\section{Lokasi Penelitian}

Lokasi penelitian secara administratif termasuk dalam wilayah Kota Surabaya dan Kabupaten Sidoarjo, Jawa Timur.

Secara geografis, daerah studi terletak pada

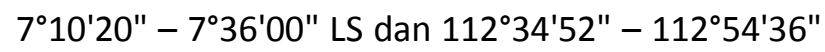
BT. Lokasi penelitian ditunjukkan pada Gambar 1.

\section{METODE PENGOLAHAN DATA}

Metode pengolahan data yang dilakukan dalam penelitian ini ditunjukkan melalui diagram alir pada Gambar 2.

Hasil yang diperoleh dari penelitian ini yaitu suatu analisis perubahan pola aliran sungai dan daerah rawan genangan di Pantai Surabaya-Sidoarjo menggunakan citra satelit penginderaan jauh.

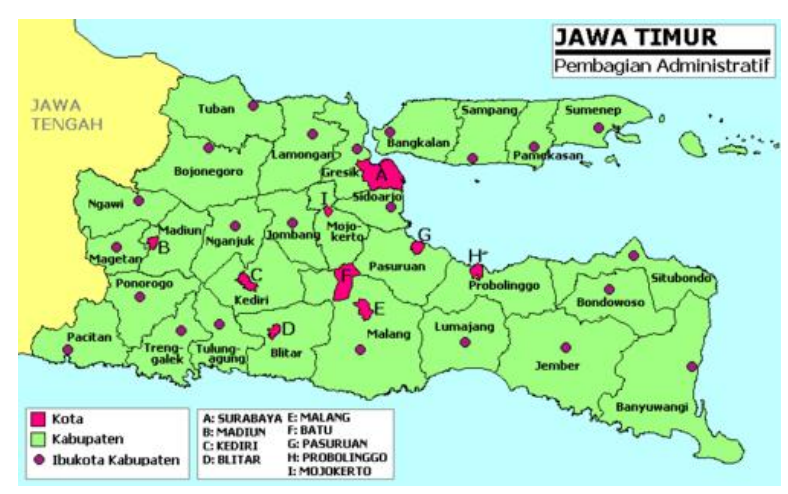

Gambar 1. Lokasi Penelitian (Pemerintah Provinsi Jawa Timur, 2013).

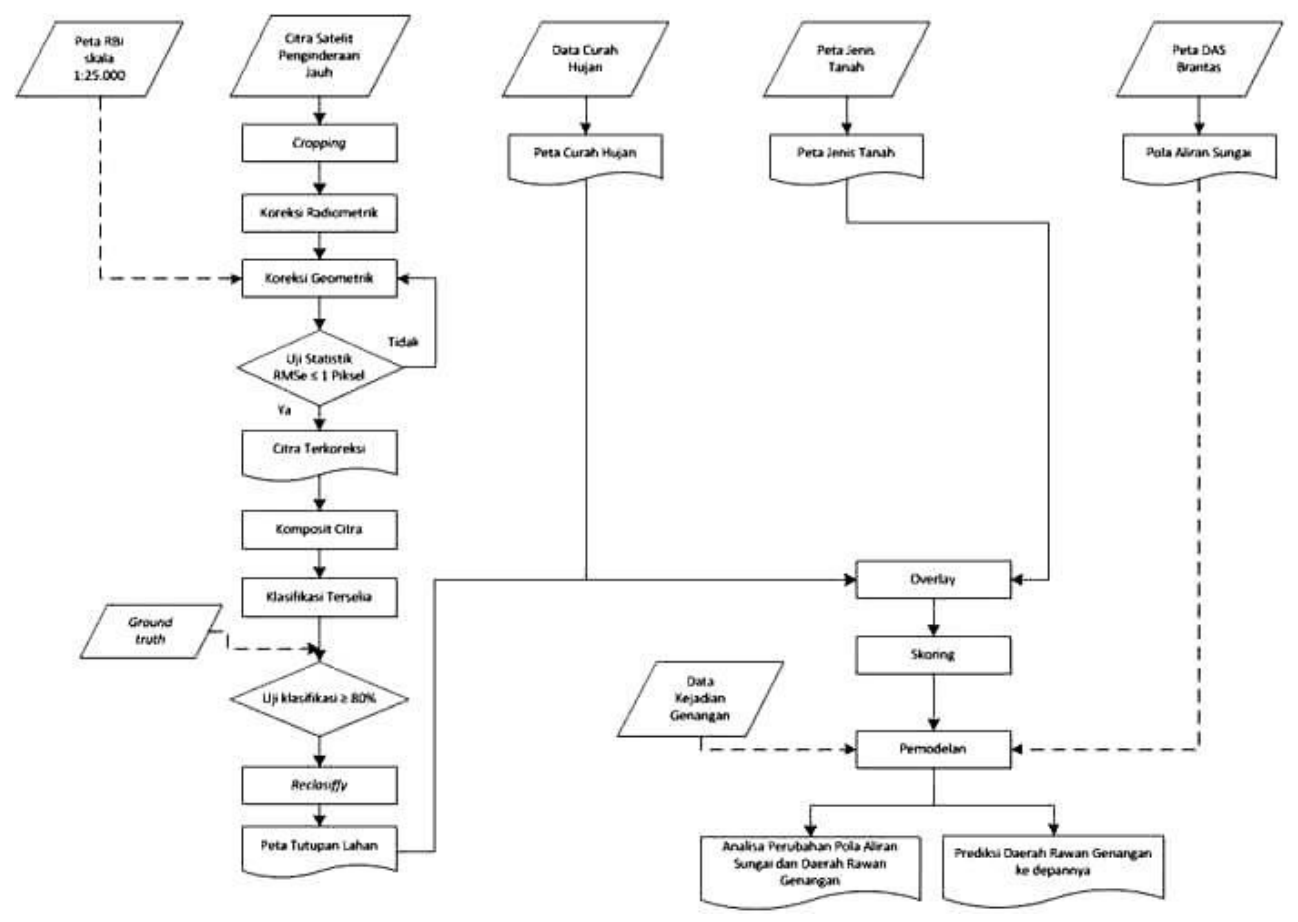

Gambar 2. Diagram Alir Penelitian. 


\section{HASIL DAN PEMBAHASAN}

Dari hasil pengolahan citra Landsat tahun 2009 diperoleh jenis dan area tutupan lahan seperti Tabel 2.

Tabel 2. Jenis dan Area Tutupan Lahan Tahun 2009.

\begin{tabular}{ccc}
\hline No. & Jenis Tutupan Lahan & Area (Ha) \\
\hline 1 & Tambak & 24749.58 \\
2 & Pemukiman & 592.95 \\
3 & Sawah & 957.66 \\
4 & Vegetasi & 15155.31 \\
5 & Lahan Terbuka & 674.60 \\
6 & Tubuh Air & 2850.41 \\
\hline
\end{tabular}

Sumber : Hasil pengolahan

Tutupan lahan terbesar didominasi oleh tambak sebesar $24749.58 \mathrm{Ha}$ (55.02\%) dan area terkecil adalah vegetasi dengan luas $15155.31 \mathrm{Ha}$ (1.50\%) dari luas seluruhnya.

Sedangkan hasil pengolahan citra Landsat tahun 2013 diperoleh jenis area tutupan lahan seperti Tabel 3.

Tabel 3. Jenis dan Area Tutupan Lahan Tahun 2013.

\begin{tabular}{ccc}
\hline No. & Jenis Tutupan Lahan & Area $(\mathrm{Ha})$ \\
\hline 1 & Tambak & 24108.91 \\
2 & Badan Air & 555.89 \\
3 & Lahan Terbuka & 284.73 \\
4 & Pemukiman & 16911.23 \\
5 & Vegetasi & 854.73 \\
6 & Sawah & 2287.37 \\
\hline
\end{tabular}

Sumber : Hasil pengolahan

Diperoleh jenis dan area tutupan lahan, tutupan lahan terbesar didominasi oleh tambak sebesar $24108.91 \mathrm{Ha}$ (53.57\%) dan area terkecil adalah tubuh air dengan luas $555.89 \mathrm{Ha}$ (1.24\%) dari luas seluruhnya.

Dari pengolahan data terjadi penambahan luasan pesisir Surabaya-Sidoarjo dari tahun 2009 2013 yakni sebesar 22.36 Ha. Penambahan ini terjadi akibat penambahan sedimentasi yang terjadi pada daerah pantai.

Untuk curah hujan tahun 2009 dan 2013 berdasarkan akuisisi citra. Berikut ini adalah tabel kriteria hujan di lokasi penelitian pada tahun 2009 2013.

Tabel 4. Kriteria Curah Hujan Lokasi Penelitian.

\begin{tabular}{cccc}
\hline No & $\begin{array}{c}\text { Curah Hujan } \\
(\mathrm{mm})\end{array}$ & $2009(\mathrm{Ha})$ & $2013(\mathrm{Ha})$ \\
\hline 1 & $\begin{array}{c}<1452 \\
\mathrm{~mm} / \text { tahun }\end{array}$ & 3845.86 & 9794.43 \\
& $\begin{array}{c}1452-1740 \\
\mathrm{~mm} / \text { tahun } \\
2\end{array}$ & 22979.87 & 13149.78 \\
& $>1740$ & 14573.27 & 16423.99 \\
\hline
\end{tabular}

Sumber : Hasil pengolahan

Jenis tanah kawasan pesisir Surabaya-Sidoarjo dapat di kelompokan menjadi 3 kelas seperti pada Tabel 5.

Tabel 5. Jenis Tanah Lokasi Penelitian.

\begin{tabular}{cccc}
\hline No & Jenis Tanah & Luas (Ha) & Area \% \\
\hline 1 & KJP & 23738.71 & 52.69 \\
2 & MKS & 21301.03 & 47.28 \\
3 & BDG & 15.67 & 0.03 \\
\hline & Total & 45055.412 & 100
\end{tabular}

Sumber : Hasil pengolahan

Dengan proses overlay akan dihasilkan data analisis. Pada data analisis, nilai skor dari setiap area dijumlahkan. Dengan membagi selisih nilai tersebut dengan 4 kelas tingkat kerawanan terhadap genangan.

Dari proses overlay beberapa peta tematik yang dijadikan parameter daerah rawan genangan dan proses skoring pada daerah penelitian didapatkan hasil luas genangan yang ditunjukkan padaTtabel 6.

Berdasarkan hasil yang ditunjukkan pada Tabel 6 Berdasarkan tingkat kerawanannya kawasan pesisir pantai Surabaya-Sidoarjo di dominasi kelas genangan sangat rawan. 
Tabel 6. Perbedaan Luas Genangan pada Tahun 2009 dan 2013.

\begin{tabular}{cccc}
\hline No & Tingkat & $2009(\mathrm{Ha})$ & $2013(\mathrm{Ha})$ \\
\hline 1 & Kurang Rawan & 463.96 & 615.82 \\
2 & Rawan & 2614.71 & 2585.46 \\
3 & Sangat Rawan & 32455.50 & 32700.90 \\
4 & Genangan & 9394.27 & 8917.57 \\
& Permanen & & \\
\hline
\end{tabular}

Sumber : Hasil pengolahan

Menurut penelitian (Ardi, 2010), kawasan pesisir pantai Surabaya-Sidoarjo didominasi kelas genangan permanen yang sebagian besar terdapat pada tutupan lahan tambak yang juga merupakan tutupan lahan terbesar pada daerah tersebut yang mengindikasikan bahwa tutupan lahan merupakan parameter terpenting yang mempengaruhi tingkat kerentanan daerah gena ngan. Namun, berdasarkan hasil penelitian kawasan pesisir pantai SurabayaSidoarjo di dominasi kelas genangan sangat rawan. Hal ini terjadi karena persebaran hujan dengan intensitas yang tinggi di daerah tersebut yaitu 1452 - 1740 mm pada tahun 2009 dan >1740 mm pada tahun 2013.

Sehingga mengindikasikan bahwa selain tutupan lahan, curah hujan juga cukup mempengaruhi tingkat kerawanan daerah genangan. Menurut penelitian yang dilakukan Bioresita Filsa (2013), curah hujan akan berpengaruh apabila disertai dengan variabel atau parameter-parameter yang lain seperti tutupan lahan, ketinggian wilayah, kelerengan dan jenis tanah untuk dapat membuat pemodelan prakiraan genangan yang tepat.

Selain parameter tutupan lahan, curah hujan dan jenis tanah, parameter lain yang dapat digunakan untuk menentukan daerah rawan genangan adalah memperhatikan Daerah Aliran Sungai (DAS) dan menghitung debit maksimumnya.

Dari hasil perhitungan dengan menggunakan metode rasional didapatkan debit maksimum pada masing-masing Sub DAS di daerah penelitian.

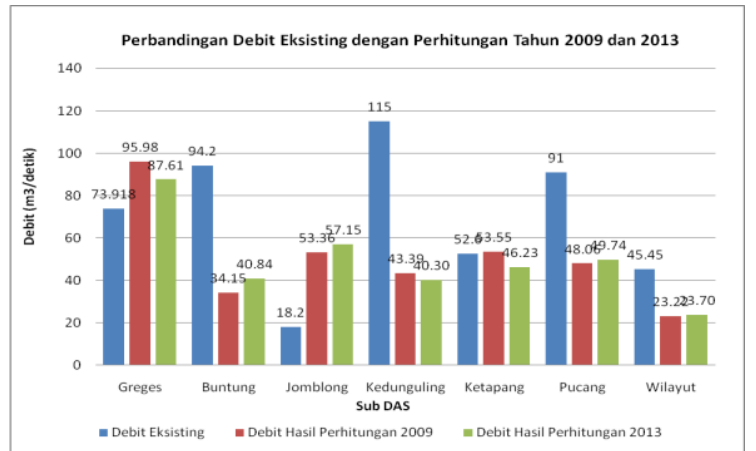

Gambar 2. Grafik Perbandingan Debit Eksisting dengan Hasil Perhitungan Tahun 2009 dan 2013.

Dari grafik di atas dapat dilihat bahwa di antara keenam Sub DAS di pesisir Sidoarjo yang telah dihitung, pada tahun 2009 ada dua nilai debit perhitungan yang lebih tinggi dari debit eksisting, yaitu Sub DAS Jomblong dan Sub DAS Ketapang. Sub DAS Ketapang hanya kelebihan debit sebesar 0.95 $\mathrm{m}^{3} /$ detik. Sedangkan Sub DAS Jomblong memiliki kelebihan debit yang sangat besar, yaitu 35.16 $\mathrm{m}^{3} /$ detik.

Dengan demikian, menurut perhitungan dengan metode rasional, pada tahun 2009 diperkirakan kedua sub DAS tersebut rawan terkena genangan air hujan. Sedangkan untuk tahun 2013, ada satu sub DAS yang memiliki nilai debit maksimum melebihi debit eksistingnya, yaitu Sub DAS Jomblong. Sub DAS Jomblong memiliki kelebihan debit sebesar $38.95 \mathrm{~m}^{3} /$ detik, dimana jumlah tersebut lebih tinggi dari tahun 2009. Sehingga dapat diartikan bahwa pada tahun 2013, kawasan rawan genangan juga akan semakin bertambah.

Berdasarkan penelitian yang dilakukan Hardaningrum dkk (2005), Sub DAS Jomblong memiliki kelebihan debit sebesar $64.82 \mathrm{~m}^{3} /$ detik, dengan tutupan lahan berupa pemukiman renggang, sawah dan tambak. Tekstur tanah di sub DAS tersebut berupa lempung dan lempung berlumpur, dimana kedua jenis ini sulit untuk menyerap air. 
Sedangkan untuk Sub DAS Greges yang merupakan salah satu sub DAS yang ada di Pesisir Surabaya, berdasarkan hasil perhitungan dari tahun 2009 dan 2013 selalu menunjukkan debit air yang tinggi. Pada tahun 2009, Sub DAS Greges memiliki kelebihan debit sebesar $22.06 \mathrm{~m}^{3} /$ detik. Sedangkan pada tahun 2013, Sub DAS Greges memiliki kelebihan debit sebesar $13.692 \mathrm{~m}^{3} /$ detik. Dengan demikian, menurut perhitungan dengan metode rasional, pada tahun 2009 dan 2013 diperkirakan sub DAS tersebut rawan terkena genangan air hujan.

Berdasarkan penelitian (Priyono, 2012), genangan yang terjadi pada Sub DAS Greges berada pada beberapa kelurahan antara lain, Kelurahan Dupak, Kelurahan Dukuh, Kelurahan Petemon, Kelurahan Simomulyo, Kelurahan Banyu Urip dan beberapa wilayah lain dengan presentase luas genangan yang sering terjadi sebesar $22.95 \%$. Tinggi genangan yang terjadi mencapai $\pm 0.5-1$ meter dan lama genangan yang terjadi $\pm 3.5 \mathrm{jam}$. Faktor-faktor penyebab timbulnya genangan pada Sub DAS Greges antara lain adalah penyumbatan sampah buangan masyarakat dan sedimentasi pada Saluran Greges dan boezem Morokrembangan yang menyebabkan berkurangnya kapasitas dalam menampung debit air hujan.

Dari permasalahan yang dianalisis pada Sub DAS Greges, maka solusi yang perlu dilakukan untuk mengatasi genangan adalah dengan merencanakan kapasitas baru atau normalisasi pada Saluran Greges. Dengan adanya dimensi baru pada saluran Greges maka debit banjir pada Sub DAS tersebut dapat dikendalikan. Hal yang sama dapat pula dilakukan untuk Sub DAS-Sub DAS yang memiliki kapasitas penampungan debit air hujan yang rendah.

Prediksi daerah rawan genangan yang didapatkan dari hasil overlay dan perhitungan debit maksimum menunjukkan hasil yang berbanding lurus. Beberapa Kecamatan yang diperkirakan merupakan daerah rawan genangan berdasarkan perhitungan, pada hasil overlay dan skoring berada pada kelas yang sangat rawan.

Sedangkan untuk pola aliran sungai pada tahun 2009- 2013 relatif tetap. Daerah pesisir Surabaya bagian Utara sampai perbatasan Sidoarjo di dominasi oleh pola aliran Paralel, sedangkan Daerah pesisir Sidoarjo lebih di dominasi oleh pola aliran sungai Dendritik.

\section{PENUTUP}

\section{Simpulan}

Berdasarkan analisis perubahan pola aliran dan daerah rawan genangan di Pesisir Surabaya-Sidoarjo tahun 2009 dan 2013, dapat disimpulkan sebagai berikut;

1. Daerah pesisir Surabaya bagian Utara sampai perbatasan Sidoarjo didominasi oleh pola aliran Paralel, sedangkan Daerah pesisir Sidoarjo lebih di dominasi oleh pola aliran sungai Dendritik.

2. Pola aliran sungai pada tahun 2009 dan 2013 relatif tetap.

3. Berdasarkan hasil pengolahan citra tahun 2009 dan tahun 2013, didapatkan jenis tutupan lahan terluas didominasi oleh kelas tambak. Dari tahun 2009 hingga tahun 2013, hampir semua jenis tutupan lahan mengalami penurunan luasan.

4. Selain perubahan tutupan lahan yang mengindikasikan adanya perkembangan pembangunan kawasan pesisir, luasan pesisir tahun 2009 dan 2013 mengalami kenaikan sebesar 22.36 Hektar. Penambahan ini dapat terjadi akibat penambahan sedimentasi di daerah pantai.

5. Berdasarkan tingkat kerawanannya, kawasan pesisir pantai Surabaya-Sidoarjo di dominasi kelas genangan sangat rawan. Hal ini terjadi karena persebaran hujan dengan intensitas yang tinggi di daerah tersebut yaitu $1452-1740 \mathrm{~mm}$ pada tahun 2009 dan $>1740 \mathrm{~mm}$ pada tahun 2013. Sehingga mengindikasikan bahwa selain tutupan lahan, curah hujan juga cukup mempengaruhi tingkat kerawanan daerah genangan.

6. Penggunaan parameter ketinggian dan kelerengan untuk daerah yang memiliki ketinggian sangat datar tidak terlalu signifikan untuk menentukan daerah rawan genangan. 
7. Selain parameter tutupan lahan, curah hujan dan jenis tanah, parameter lain yang dapat digunakan untuk menentukan daerah rawan genangan adalah memperhatikan Daerah Aliran Sungai (DAS) dan menghitung debit maksimumnya.

8. Pada tahun 2009 diperkirakan Sub DAS Greges, Jomblong dan Ketapang rawan terkena genangan air hujan. Sedangkan untuk tahun 2013, ada dua Sub DAS yang memiliki nilai debit maksimum melebihi debit eksistingnya, yaitu Sub DAS Greges dan Jomblong.

\section{Saran}

Adapun saran yang dapat disampaikan pada penelitian ini :

1. Untuk mengetahui pola aliran sungai, perlu dilakukan lagi penelitian lebih mendalam dengan memperhatikan parameter-parameter lain seperti terjadinya pendangkalan, penyempitan atau pelebaran sungai dan lainlain.

2. Untuk menentukan daerah rawan genangan, perlu adanya penambahan parameterparameter lain seperti struktur geologi, kejadian pasang-surut, dan lain-lain.

3. Perlu memperhatikan kondisi topografi daerah penelitian jika akan menggunakan parameter ketinggian dan kelerengan dalam menentukan daerah rawan genangan.

\section{DAFTAR PUSTAKA}

Ardi, Linda Oktareni., 2010. Determining Flood Retention Area Using Technology Of Remote Sensing And Geographical Information System (Study Case : Mojokerto regency). Faculty of Civil Engineering and Planning

Bioresita, Filsa., 2013. Analisa Potensi Genangan Berdasarkan Data Curah Hujan Global Berbasis Penginderaan Jauh. Program studi Teknik Geomatika ITS. Surabaya

Edi, Susilo. Bambang Sudarmanto., 2012. Kajian Hidrologi terhadap Perubahan Penggunaan Lahan Pertanian dan Lahan Hijau Menjadi Pemukiman di Kota Semarang. Riptek, Vol. 6, No. I, Tahun 2012, hh : $1-7$
Hardaningrum, Farida, M. Taufik dan Bangun Muljo S., 2005. Analisis Genangan Air Hujan di Kawasan Delta dengan Menggunakan Penginderaan Jauh dan SIG. Pertemuan IImiah Tahunan MAPIN XIV.

Idris Mirzanur., 2007. Analisi Limpasan dan Genangan Air Hujan dengan Digital Elevetion Model Menggunakan Software Arcgis 9.2. Program studi Teknik Geomatika ITS. Surabaya

Lillesand T.M., and Kiefer R.W., 1994. Remote Sensing and Image Interpretation. Second Edition, John Wiley \& Sons, New York

Pemerintah Provinsi Jawa Timur,. 2013. Peta Administrasi Provinsi Jawa Timur. (URL:http://www.travellers.web.id/discoverindonesia/java-region/east-java/), diakses pada tanggal 21 Februari 2014

Priyono, Sapto Pipit., 2012. Studi Penanggulangan Banjir dan Penanganan DAS Saluran Greges Surabaya. ITS Surabaya.

Purwadhi, Sri Hardiyanti., 2001. Interpretasi Citra Digital. Jakarta: PT. Gramedia Widiasarana

Susilowati. Tima Santita N.R., 2006. Analisis Perubahan Tata Guna Lahan dan Koefisien Limpasan terhadap Debit Drainase Perkotaan. Media Teknik Sipil. Universitas Sebelas Maret. Surakarta. Januari 2006. 